九州大学学術情報リポジトリ

Kyushu University Institutional Repository

\title{
Vertebral Count And Growth Of Japanese Anchovy, Engraulis Japonicus Temminck And Schlegel
}

Aikawa, Hiroaki

Fisheries Laboratry, Department of Agriculture, Kyusyu University

Hayashi, Tomoo

Furuno, Yasuo

https://doi.org/10.5109/22629

出版情報：九州大学大学院農学研究院紀要. 9 (3)，pp. 255-269，1950-01. Kyushu University バージョン：

権利関係 : 


\title{
VERTEBRAL COUNT AND GROWTH OF JAPANESE ANCIIOVY, ENGRAULIS JAPONICUS TEMMINCK AND SCHLEGEL
}

\author{
llikonkt Alkawa, Tomoo HaYashi and Yasuo furdino
}

Japanese anchovy, Engratulis japonicus Termminck and Schlegel, is one of the most important neritic fishery resources in Japan and its annual yield amounts to 225,000 gramtons on an average, occupying $5 \%$ or a little less of the total yield of Japanese clupeoid fishes (Pacific herring excluded). Anchovy has a wide range of distribution in the Japanese waters from South Sakhalin and Hokkaido in the north to Kyûshû in the south, although it is very common in the South Japan region and also on the south coast of Korea. Anchovy fishery takes place nearly all year round in the southem tishing ground and the peak of the season seems to be in winter. However, in the northern grounds the fishing season is rather shortened and its peak is shifted gradually towards summer.

Body length frequency polygon reveals three major modes. The whitebait group occupies the smallest mode under $50 \mathrm{~mm}$, the medium sized group the medium mode from 50 to 90 or $100 \mathrm{~mm}$ and the large sized group the largest mode above 90 or $100 \mathrm{~mm}$. The whitebait groups are present nearly all year round in such southern seas as around Kyûshû and on the southern Pacific coast, becoming scarce in winter on the northern Japan Sea crast and on the Pacific coast north from Cape Inubô, but they arc never recorded around Hokkaidô and Sakhalin eyen in summer.

Probably due to the selective power of fishing gear and also due to the long duration of the spawning season, the whitebait 
groups show no remarkable seasonal change in size and, in addition, the occurrence of eggs and larvae are so scattered in time and space that it is very difficult to make any accurate statement regarding its life history. Previously T. Nishikawa (1901) found two peaks in the occurrence of eggs and larvac in Suruga Bay and considered that the Japanese anchovy could spawn in winter and also in summer. Two peaks were also noted in the fishing season of whitebait groups off Aki in Tosa Bay as is shown in Table 1 .

Tablc 1. Seasonal change in catch of whitebait group off Aki in Tosa Bay.

\begin{tabular}{|c|c|c|c|c|c|c|}
\hline \multirow{2}{*}{ Month } & \multicolumn{2}{|c|}{ Aki } & \multirow{2}{*}{ Month } & \multicolumn{2}{|c|}{ Alii } & \multirow{2}{*}{$\begin{array}{c}\text { Susaki } \\
1939\end{array}$} \\
\hline & 1938 & 1939 & & 1938 & 1939 & \\
\hline January & 31294 & 1197 & July & - & 3180 & 4520 \\
\hline liebruary & 25144 & $30-113$ & August & 44843 & 2914 & 1028 \\
\hline Narih & 13875 & 31883 & Septrmber & 31538 & 8366 & $2.577 \%$ \\
\hline April & 5968 & 25973 & October & 25541 & 27870 & $15199 \%$ \\
\hline Maty & 14606 & 35824 & November & 13215 & 23355 & 31185 \\
\hline June: & 5963 & 39443 & December & 9420 & 13354 & $?$ \\
\hline
\end{tabular}

The whitebait groups are composed not only of the larvat of anchovy, but also of sardine (Sardinia melanosticta) and of Japanese murray (Etrumeus microps) in addition to several neritic fishes. The larval composition of whitebait groups varies seasonally and locally (Table 2).

Table 2. Seasonal change in the composition of whitebait group.

\begin{tabular}{|c|c|c|c|c|c|c|c|c|}
\hline \multirow{2}{*}{ Locality } & \multirow{2}{*}{\multicolumn{2}{|c|}{ bate }} & \multicolumn{3}{|c|}{ Composition $(\%)$} & \multicolumn{3}{|c|}{ Anchovy } \\
\hline & & & $\mathrm{S}$ & $\mathrm{M}$ & A & no. & $\operatorname{lnm}$ & $w \mathrm{Ing}$ \\
\hline Susati & I & 12,37 & - & - & 100 & 一 & - & $\longrightarrow$ \\
\hline , & &,- 38 & 7 & 5 & 88 & - & - & $\ldots$ \\
\hline , & II & 15,37 & 51 & 22 & 27 & - & - & - \\
\hline , & &,- 38 & 93 & 2 & 5 & 278 & 32 & 15 \\
\hline Aburatsubo & & 28,37 & 24 & 17 & 59 & 405 & 32 & 10 \\
\hline Susaki & III & $12, ' 37$ & 91 & 1 & 8 & - & $\cdots-$ & -- \\
\hline Aburatsubo & & 15. & 92 & 2 & fi & 29 & 30 & 7 \\
\hline Yoshida & & $19, "$ & 96 & - & 4 & $y$ & 30 & 11 \\
\hline Totoro & IV &,$-^{\prime} 38$ & 69 & 10 & 21 & - & $\cdots$. & $\cdots$ \\
\hline
\end{tabular}




\begin{tabular}{|c|c|c|c|c|c|c|c|c|}
\hline Susaki & & 1 , " & - & 1 & 99 & - & - & $m$ \\
\hline Fukuoka & & 7, & $\ldots$ & 98 & 2 & - & - & - \\
\hline Aburatsuloo & & 11,37 & 44 & - & 56 & 219 & 27 & 5 \\
\hline Yoshida & & $14, "$ & .81 & - & 19 & 32 & 36 & - \\
\hline Owase & $V$ & $28, / 38$ & 18 & $\cdots$ & 82 & 82 & 35 & - \\
\hline Aburatsubo & & $10, / 37$ & 2 & - & 98 & 446 & 35 & 20) \\
\hline Yoshida & & $10, "$ & 24 & 1 & 75 & 375 & 29 & 10 \\
\hline Hamada & VI & 4,36 & - & 93 & 7 & - & - & - \\
\hline Ezumi & & $9, \quad 1$ & 91 & 5 & 1 & - & - & - \\
\hline Yoshidia & & 10,37 & - & - & 100 & 259 & 24 & 5 \\
\hline Susaki & & $12, "$ & 5 & 5 & 90 & - & - & - \\
\hline Hi-no-Misaki & & 27,36 & 43 & 55 & 2 & - & - & - \\
\hline Hamada & & $28, "$ & 74 & 1 & 25 & -- & - & - \\
\hline Aburatsubo & VII & $1, / 37$ & 82 & 7 & 11 & 51 & 25 & 1 \\
\hline Yoshida & & $8, "$ & - & $\ldots$ & 100 & 228 & 49 & 55 \\
\hline Kasurni & & 8,36 & 66 & 26 & 8 & - & - & - \\
\hline I'ukuoka & & $9, ' 38$ & 38 & 4 & 58 & 一 & - & - \\
\hline Aburatsubo & Vil & 6,37 & -- & 31 & 69 & 230 & 22 & -... \\
\hline Aburatsubo & & 16,37 & - & 58 & 42 & 211 & 24 & 7 \\
\hline Yoshida & IX & $22, "$ & - & - & 100 & 821 & 27 & 8 \\
\hline Aburatsubo & $\mathrm{x}$ & $23, "$ & - & 3 & 97 & 541 & 30 & $\cdots$ \\
\hline , & & $10, " 1$ & -- & 2 & 98 & 319 & 33 & 19 \\
\hline , & & $28, " 1$ & -- & 56 & 44 & 186 & 25 & 4 \\
\hline Susaki & $\mathrm{XI}$ & $15, "$ & 72 & 20 & 8 & - & . & $\ldots$ \\
\hline Aburatsubo & & $18, "$ & - & 71 & 29 & 189 & 26 & 5 \\
\hline Yoshidit & & $28, "$ & - & - & 100 & .120 & 32 & 14 \\
\hline Aburatsubo & & $29, " 1$ & - & 79 & 21 & $3 !$ & 32 & 12 \\
\hline Kasumi & XII & $1, ' 36$ & - & - & 100 & $-\ldots$ & - & $\ldots$ \\
\hline Susaki & & $15,,^{\prime} 37$ & - & 72 & 28 & 18 & - & 11 \\
\hline Aburatsubo & & $20, " 1$ & - & 40 & (i) & 198 & 33 & 19 \\
\hline
\end{tabular}

S: sardine, M: murray, A: anchovy.

The sardine of whitebait stage (less than $50 \mathrm{~mm}$ in length) is generally prevalent among the catch during the first half of a year and the murray of whitebait stage during the latter half. Nevertheless, the anchovy of whitebait stage is always prevalent, being especially abundant from early spring to autumn. The vernal peak in the occurrence of whitebait groups seemed to bo associated with the prevalence of the larvae of sardine and anchovy and on the other hand the autumnal peak with dominance of 
larvae of murray and anchovy along the Pacific coast. Apparently from the occurrence of the whitebait groups, anchovy can be corrsidered to spawn twice a year.

Anchovy of the Mediterranean Sea (Engraulis encrasicholus), ranging from 80 to $160 \mathrm{~mm}$ in average length, is generally sinalles than the anchovy on the Atlantic coast of Europe. It seems probable that spawning takes place in summer and again in winter, although egg-production is usually far larger in amount in summer than in winter. Among the Australasian anchovies (E. australis), there exist many different races at different localities. considered from the occurrence of eggs and larvae. They are liable to occur densely in such localitles as on the coast from New South Wales to Queensland, from Victoria coast to Tasmania, around the New Zealand, on the south coast and also on the southwest coast of Australia. The specimens measured in any locality range from 40 to $130 \mathrm{~mm}$ in total length and $70-80 \mathrm{~mm}$ groups are generally prevalent everywhere. Mature anchovies are recorded both in summer and in winter. In several respects, the Australasian anchovies closely resemble the Japant'se anchovy.

Based upon the vertebral count, which has becn used in the study of race, the present authors could divide anchovy collections around Japan into two different groups and then easily trace seasonally the growth process of each group. At first, vertebral count was made for whitebait collections in 1936 and 1937, which were preserved in formalin (Table 3).

Table 3. Vertebral count of whitebait group.

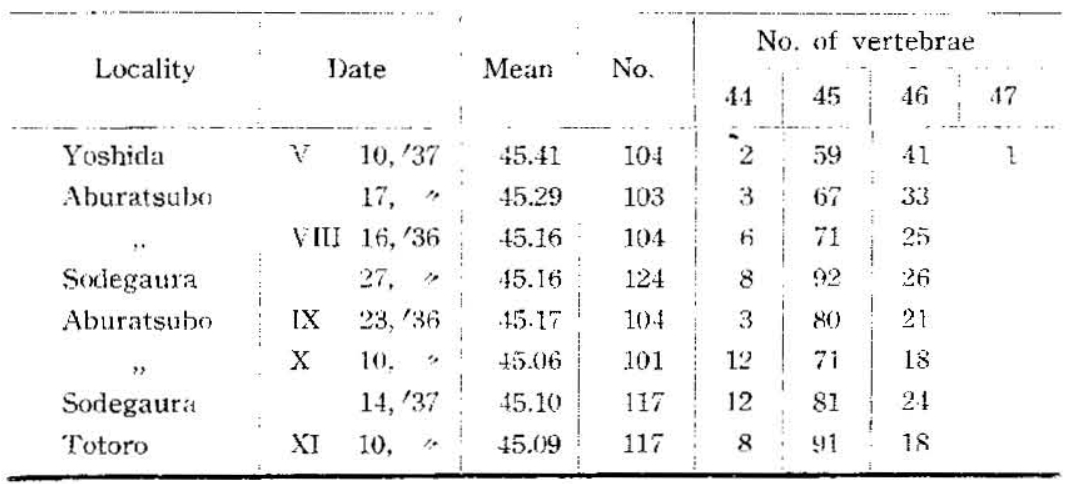

Note: hypural included. 
The significance in the difference of numbers of vertebrae between any two collections is tested with chi-square method under the assumption that both collections will follow the same variation law in the number of vertebrae. When P-value, known from chi-square value, is higher than 0.05 . the difference indicated is nonsignificant and both collections are considered to belong to the group of the same origin. On the other hand, when P-value is less than 0.05 or 0.01 , the difference is highly significant and both collections are probably different from each other.

The differences of the vertebral numbers between the Abura. tsubo collection in May 45.29 and any one of the Aburatsubo collections in August (45.16), in September (45.17) and in October (45.06) are all indicated as highly significant. However, all the collections after August in different localities and in different years are not significantly different from each other, as $\mathrm{P}$-values are always higher than 0.05 (Table 3 ). Accordingly, the number of vertebrae seems to vary seasonally, but neither locally nor annually. To prove this conclusion, many anchovy samples were collected from different localities in different seasons since 1943 (Fig. 1). The details of measure of body proportion and the vertebral count are given in Tables 4 and 5 .

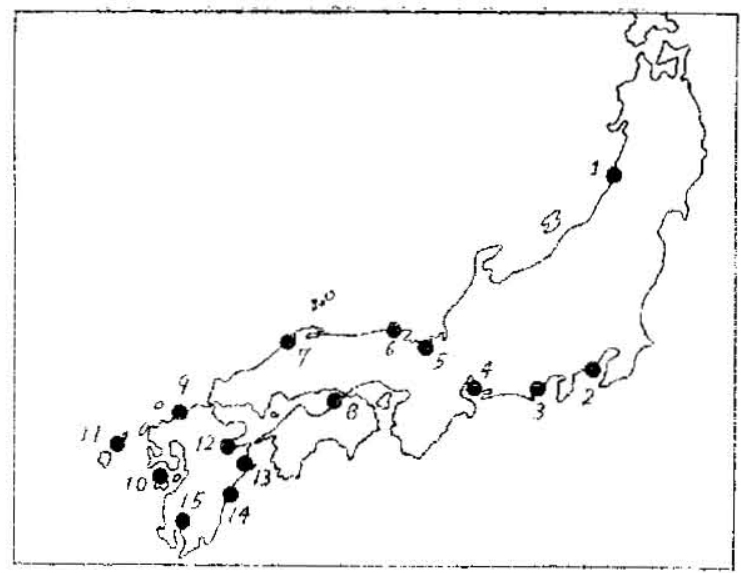

Fid 1. Jowal stations where anchovy samples were collecterl. 1. Sodegaura, ?. Aburatsubo, 3. Yoshida, 4. Toyohana, 5. Miyazi, 6. Kasumi and Hi-no-Misaki, $\therefore$ Hamada and Ezumi. 8. O-Sima, 9. Ai noSima, Futuoka, harastomari and Fukae, 10. Tonioka. 11. Goto-Ave, 12. Beppu, 13. Kamae, 14. Totoro, 15. Kagoshima 
Table 4. Seasonal change in size and weight of Japanese anchovy.

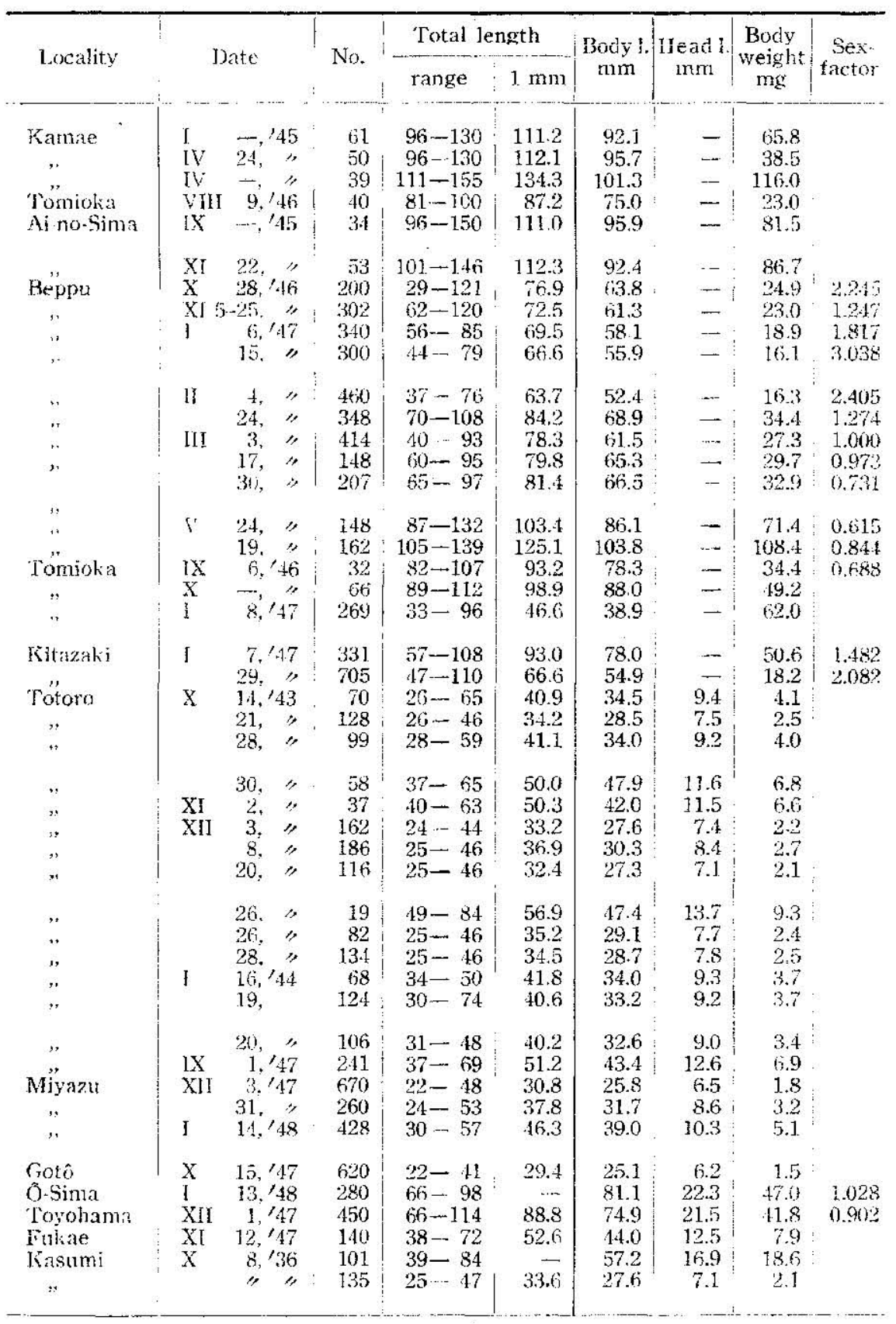


Table 5. Results of the vertebral counts for Japanese anchovy.

\begin{tabular}{|c|c|c|c|c|c|c|c|c|c|c|c|}
\hline \multirow{2}{*}{ Locality } & \multirow{2}{*}{\multicolumn{2}{|c|}{ Date }} & \multirow{2}{*}{$\begin{array}{l}\text { Mean no. } \\
\text { of vertebrae }\end{array}$} & \multirow{2}{*}{ Size } & \multicolumn{6}{|c|}{ Number of vertebrae } & \multirow{2}{*}{ Sum } \\
\hline & & & & & 42 & 43 & 44 & $4: \overline{3}$ & 46 & 47 & \\
\hline Kasumi & $\mathrm{X}$ & $8,,^{\prime} 36$ & $45.05 \pm 0.49$ & $\mathrm{~W}$ & - & t & 13 & $10^{\prime}$ & 20 & - & 135 \\
\hline Totor & & $14, / 43$ & $45.03 \pm 0.59$ & W & - & 1 & 8 & 49 & 12 & - & 70 \\
\hline ", & & 21." & $45.12 \pm 0.53$ & W & - & - & 1] & 90 & 27 & $\ldots$ & 128 \\
\hline 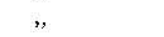 & & 28 , " & $45.14 \pm 0.53$ & W & - & 一 & 8 & 69 & 22 & - & 99 \\
\hline$"$ & & $30, " 1$ & $45.19 \pm 0.54$ & W & _ & - & 4 & 39 & 15 & - . & 58 \\
\hline$\because$ & $\mathrm{XI}$ & $2, "$ & $45.14 \pm 0.53$ & W & - & - & 2 & 29 & 5 & 1 & 37 \\
\hline .. & & $3, " 1$ & $45.12 \pm 0.48$ & W & -- & $-\rightarrow$ & 10 & 122 & 30 & -1 & $16: 2$ \\
\hline$"$ & & $8, " 1$ & $45.11 \pm 0.53$ & W & - & $I_{1}$ & 13 & 135 & 37 & $一$ & 186 \\
\hline , & & 20 , " & $45.08 \pm 0.49$ & W & i - & -1 & 10 & 87. & 19 & - & 116 \\
\hline$\cdot$ & & $26, "$ & $45.11 \pm 0.46$ & $W$ & - & -- & 5 & 80 & 1f: & 一 & 101 \\
\hline 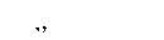 & & $28, "$ & $45.07 \pm 0.47$ & W & - & - & 10 & 104 & 20 & - & 134 \\
\hline . & 1 & 19,45 & .59 & W & - & -1 & 12 & 88 & 21 & $3 !$ & 124 \\
\hline & & $20, "$ & $45.12 \pm 0.56$ & W & - & - & 11 & 71 & 24 & - & 106 \\
\hline Kamate & VIII & $9, / 45$ & $45.07 \pm 0.35$ & $\mathrm{~L}$ & - & 1 & $9 !$ & $4 \dot{r}$ & $3 \%$ & $\cdots$ & 73 \\
\hline Tomiolia & I & 8.146 & $45.02 \pm 0.62$ & $\mathrm{M}$ & - & - & 33 & $17 t$ & $55^{1}$ & 1. & 265 \\
\hline Beppu & I & 6,47 & $45.07 \pm 0.56$ & M & - & 2 & 41 & 221 & 69 & $\ldots$ & 333 \\
\hline$"$ & & 7,1 & 45. & M & - & - & 28 & 229 & 73 & - & 3330 \\
\hline , & & $1 \overline{5}$, & $45.02 \pm 0.62$ & M & 1 & 1 & 43 & 198 & 50 & 2 & 295 \\
\hline$n$ & II & 4." & $45.06 \pm 0.55$ & M & - & 1 & 53 & 312 & $81:$ & - & 447 \\
\hline " & & $24, "$ & $45.12 \pm 0.55$ & M & $\longrightarrow$ & -- & 37 & 236 & 74 & 2 & 349 \\
\hline " & III & $3, " 1$ & 45.1 & $M$ & - & - & 36 & $282:$ & 85 & - & $40 \%$ \\
\hline 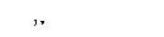 & & $17, "$ & 0.52 & M & - & $\rightarrow$ & 10 & 102 & 32 & - & 144 \\
\hline & & $30, "$ & $45.12 \pm 0.54$ & M & - & - & 19 & 145 & 41 & 1. & 206 \\
\hline Goto-Ave & $\mathrm{X}$ & $15, "$ & $45.05 \pm 0.60$ & W & - & 6 & 78 & 119 & 116 & 1 ! & 620 \\
\hline Fukac & $\mathrm{XI}$ & $12, "$ & $45.16 \pm 0.62$ & $W$ & - & 一 & 14 & 92 & $3 i$ & 3 & 140 \\
\hline Miуazu & XII & $3, "$ & 45. & W & - & 12 & 84 & 428 & 141: & 5 & (67) \\
\hline$"$ & & 21 , " & 45 & W & 3 & 2 & 35 & 169 & 54 & - & 260 \\
\hline & I & $14, ' 48$ & 50.52 & M & - & 1 & 42 & 314 & 71 & & 428 \\
\hline Kagosl & $\mathrm{XI}$ & $4, "$ & $45.00 \pm 0.70$ & M & - & 1 & $\rightarrow$ & 7 & 2 & - & 16 \\
\hline Kasum & $\mathrm{X}$ & $8, ' 36$ & $45.32 \pm 0.61$ & M & & & 8 & 53 & 40 & - & 101 \\
\hline hamme & I &,$- / 45$ & 15 . & L & - & & 2 & 23 & 14 & - & 39 \\
\hline & IY & 20 , " & $35.39 \pm 0.65$ & L & - & 1 & 8 & 56 & 18 & - & 83 \\
\hline Ai-no-Sima & IX & - , " & $45.33 \pm 0.33$ & $\mathrm{~L}$ & $\cdots$ & - & 1 & 12 & 8 & -1 & 21. \\
\hline (א" & XI & $22, "$ & $45.65 \pm 0.28$ & L & 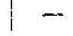 & 一 & - & 14 & 1.4 & 3 & 31 \\
\hline Tomiokia & VIII & $24, ' 46$ & $45.35 \pm 0.54$ & M & - & $\cdots$ & 2 & 8 & 6 & 1. & 17 \\
\hline & IX & fi, " & 45. & $\mathrm{M}$ & $\cdots$ & - & $\ldots$ & 18 & 14 & $\cdots$ & 32 \\
\hline Bep & $X$ & $28, "$ & 45 & M & 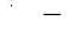 & -- & 7 & 1.24 & 61 & 6. & 198 \\
\hline Karackonari & I & 29,477 & $=0.54$ & M & 一 & | & 43 & 465 & 184 & 1 & 693 \\
\hline Верри & V & $24, "$ & $45.43 \pm 0.54$ & I. & - & - & 13 & 93 & 40 & 2 & 148 \\
\hline , & VI & $19, "$ & $45.32 \pm 0.61$ & I. & & 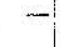 & 11 & 87 & 63. & 1 & $16 i 2$ \\
\hline Potoro & IX & $t, "$ & $=0.60$ & W & - & - & 15 & 154 & 67 & 5 & 241 \\
\hline & A & $25, \quad$ " & $45.26 \pm 0.58$ & M & $\rightarrow$ & 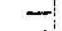 & 19 & 189 & 91 & 3 & 302 \\
\hline Foyohama & Xil & $1, "$ & $45.25 \pm 0.56$ & M & & 1 & 21 & 295 & 130 & 3 & $45 t i$ \\
\hline O-Sim & $I^{2}$ & $3,^{\prime} 48$ & $45.27 \pm 0.63$ & L & $-!$ & 2 & 13 & $18 \mathrm{I}_{j}$ & 75 & 9 & 281 \\
\hline Kagostima & XI & 4,11 & $45.36 \pm 0.72$ & I & - & - & $-!$ & 28 & 11 & -- & $4: 3$ \\
\hline ", & XII & 8,1 & $45.36 \pm 0.72$ & L & - & 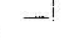 & 4 & 21 & 15 & 2 & 12 \\
\hline
\end{tabular}

Note: W-whitebait group, $\mathrm{M}$-medium sized group, L-large sized group, 
On seeing the frequency distribution of the average numbers of vertebrae within the range from 45.00 to 45.65 , there occur two modal groups, that is, the lower modal group ranging from 45.06 to 45.15 and the higher one from 45.31 to 45.35 , both groups being separated by the range from 45.16 to 45.25. Among eighteen collections in 1947, the Gotô-collection (October 15) is selected as a standard and the differences in the average numbers of vertebrae between the standard collection and any one of other seventeen collections are tested with the chisquare method (Table 6). Disregarding the size of fish and the date of collection, the differences are always indicated as nonsignificant between the collections with the vertebral numbers less than 45.20 , while they are highly significant between the standard and all the collections with the vertebral numbers greater than 45.20

Table 6. Chi-square test for the differences in the vertebral numbers with the standard collection in Gotô.

\begin{tabular}{|c|c|c|c|c|c|c|}
\hline Locality & Group & $\begin{array}{c}\text { Average } \\
\text { length } \\
\text { (mm) }\end{array}$ & $\begin{array}{l}\text { Average } \\
\text { vert. no. }\end{array}$ & $n$ & $x^{2}=$ & P \\
\hline Веррu & M & 70 & 45.07 & 3 & 0.7742 & 0.8 \\
\hline , & M & 92 & 45.14 & 2 & 5.9109 & 0.05 \\
\hline .. & M & 67 & 45.02 & 4 & 2.7883 & $>0.5$ \\
\hline , & $\mathrm{M}$ & 64 & 45.06 & 3 & 2.6799 & $>0.30$ \\
\hline .. & $\mathbf{M}$ & 84 & 45.12 & 3 & 3.446 .4 & $>0.3$ \\
\hline$"$ & M & 78 & 45.12 & 2 & 5.4370 & $>0.05$ \\
\hline " & M & 80 & 45.15 & 2 & 5.4166 & $>0.05$ \\
\hline , & M & 81 & 45.12 & 3 & 2.6911 & $>0.3$ \\
\hline Fukae & M & 53 & 45.16 & 3 & 7.6095 & $=0.05$ \\
\hline ” & W & 31 & 45.14 & 4 & 5.5916 & $>0.2$ \\
\hline Miyazu & $W$ & 38 & 45.06 & 3 & 0.7222 & 0.8 \\
\hline Karadomari & M & 67 & 45.21 & 3 & 27.1545 & 0.01 \\
\hline Beppu & L & 110 & 45.43 & 3 & 92.1087 & 0.01 \\
\hline , & I. & 125 & 45.32 & 3 & 32.5536 & 0.01 \\
\hline Totoro & $\mathrm{W}$ & 43 & 45.26 & 3 & 30.4927 & $\because 0.01$ \\
\hline , & M & 73 & 45.26 & 3 & 470.8733 & 0.01 \\
\hline Toyohama & $\mathrm{M}$ & 82 & 45.25 & 4 & 328.2798 & 0.01 \\
\hline
\end{tabular}

Note: W: wheitebait group, $\mathrm{M}$ : medjum sized group, L: large sized group. 
Treated together the collections in Beppu Bay from January to May, 1947, the body length frequency polygon reveals two major groups (Fig. 2). $70 \mathrm{~mm}$ (medium sized) group of lower mode is

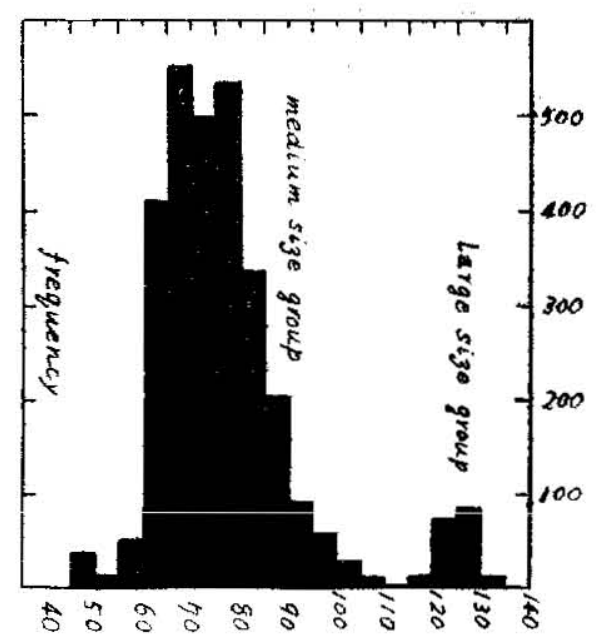

Fig. 2. Body length frequency polygon of anchovies caught in Beppu Bay from January to May, 1947

less in the number of vertebrae than $125 \mathrm{~mm}$ (large sized) group. The difference of the vertebral numbers between these two groups is indicated highly significant (Table 7).

Table 7. Chi-square test for the difference of the numbers of vertebrae between the medium and large sized groups collected in Beppu Bay from January to May. 1947.

\begin{tabular}{|c|c|c|c|c|c|c|c|c|c|}
\hline \multirow{2}{*}{ Group } & \multirow{2}{*}{$\begin{array}{l}\text { Range } \\
(\mathrm{mm})\end{array}$} & \multirow{2}{*}{$\begin{array}{l}\text { Average } \\
\text { vert. no. }\end{array}$} & \multirow{2}{*}{ No. } & \multicolumn{6}{|c|}{ Number of vertebrae } \\
\hline & & & & 42 & 43 & 44 & 45 & 46 & 47 \\
\hline 70) $\mathrm{nm}$ & $35-115$ & 45.16 & 2370 & 1 & 4 & 250 & 1605 & 504 & 6 \\
\hline $125 \mathrm{~mm}$ & $116-140$ & 45.34 & 32 & & & & 22 & 9 & 1 \\
\hline
\end{tabular}

Accordingly, the anchovy collections are divided into two grouns, one of which possesses the average number of vertebrae lower than 45.20 and another that higher than 45.20 . From Table 
3. it is easily known that the groups with lower vertebral number are present as the whitebait group mainly in autumn and also as medium sized group in spring. On the other hand, the groups with higher vertebral number appear as whitebait group in spring and as medium sized group from summer to autumn. The large sized groups are of the group with higher vertebral number in winter, while they are of that with lower number in summer. Considered from the occurrences of these two groups, all groups with higher vertebral number will be originated from the offsprings spawned in winter and those with lower vertebral number from the offsprings in summer. Here, the groups with higher vertebral number may be called as the winter offspring group and those with lower number as the summer offspring group.

For each of different offspring groups, the total collections of a separate year and grand total collection of all years are given in Table 8. Among the same offspring groups, the differences of the numbers of vertebrae between the grand total collection and any total collection of each separate year are nearly always indicated as nonsignificant ( $\mathrm{P}-0.05)$, except the summer offspring group in 1943 (P 0.01). Therefore, the annual variation in the number of vertebrae is considered nonsignificant among the same offspring group. On the contrary, the differences of the vertebral numbers between the different offspring groups of all years also of any separate year, except 1945, are always highly significant. The differences in the numbers of vertebrae are certainly considered scasonal in nature rather than annual and geographical (Tables 8 and 9$)$.

Table 8. Chi-square test for the differences between the gland total collection and each total collection of a separate year.

\begin{tabular}{|c|c|c|c|c|c|c|c|c|c|c|c|}
\hline \multirow[b]{2}{*}{ Year:- } & \multirow{2}{*}{$\begin{array}{c}\text { Average } \\
\text { no. of } \\
\text { vertebrae }\end{array}$} & \multirow[b]{2}{*}{ No. } & \multicolumn{6}{|c|}{ Number of vertebrate } & & \multirow[b]{2}{*}{$x^{2}$} & \multirow[b]{2}{*}{$\mathrm{P}$} \\
\hline & & & 42 & 43 & 44 & 45 & 46 & 47 & & & \\
\hline & & 135 & - & - & 13 & 102 & 20 & - & 2 & & \\
\hline & & 10 & - & 2 & 81 & 804 & 203 & 1 & 3 & & \\
\hline & & 230 & $\ldots$ & - & 23 & 159 & 4 & 3 & S & & \\
\hline & & 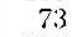 & - & 1 & 9 & 46 & 17 & $-\cdots$ & 2 & & \\
\hline & & $26 \overline{5}$ & 1 & $\ldots$ & 33 & 176 & 55 & 1 & 2 & & 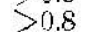 \\
\hline 1 & & 4197 & - & 24 & 478 & 2833 & 847 & 14 & 4 & & 0.3 \\
\hline 3948 & & 439 & - & 2 & 42 & 321 & 73 & - & 2 & 6.4213 & (1). 02 \\
\hline 11 years & 45.09 & 6430 & 1 & 29 & 680 & 4441 & 1260 & 19 & 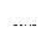 & - & - \\
\hline
\end{tabular}




\begin{tabular}{c|r|r|r|c|r|r|r|rr|r|r|r}
\hline 1936 & 45.32 & 101 & - & - & 8 & 53 & 40 & - & 2 & 4.7620 & $=0.05$ \\
1945 & 45.27 & 174 & - & 1 & 11 & 105 & 54 & 3 & 2 & 1.6610 & 0.7 \\
1916 & 45.35 & 247 & - & - & 9 & 150 & 81 & 7 & 2 & 2.9115 & 0.2 \\
1947 & 45.24 & 1996 & - & 1 & 122 & 1283 & 575 & 15 & 3 & 3.5090 & 0.1 \\
1948 & 45.29 & 364 & - & - & 17 & 230 & 104 & 11 & 3 & 7.2489 & 00.05 \\
All years & 45.26 & 2882 & - & 2 & 167 & 1821 & 854 & 36 & - & - & - \\
\hline
\end{tabular}

Table 9. Chi-square test for the differences of the game year classes.

\begin{tabular}{c|c|c|c}
\hline Year & $n$ & $x^{2}$ & $\mathrm{P}$ \\
\hline 1936 & 2 & 18.1966 & $<0.01$ \\
19.3 & 2 & 4.2638 & 0.1 \\
1946 & 2 & 22.0603 & $<0.01$ \\
1947 & 4 & 100.3590 & 0.01 \\
1948 & 2 & 26.6076 & 0.01 \\
All years & 4 & 191.9838 & 0.01 \\
\hline
\end{tabular}

C. L. Hubbs (1925) found the males of northern anchovy (Engranlis mordax mordax) to have a slightly higher vertebral number (45.77) than the female (45,65), although he considered the difference 0.12 excess for the males) to be "of probable but hardly certain significance" The sexual dimorphism in vertebral number was found highly significant for the elasmobranch (Spinax niser) by R. C. Punnett (1901) and also for capelin (Mallotus villosus) by J. L. Hart (1937). Although the sex factor (the number of females divided by that of the males, varies seasonally in considerable extent $(0.6-3.0)$, the differences of the numbers of vertebrae are always nonsignificant among the same collection as is shown in Table 10 .

Table 10. Comparison of the numbers of vertebrae between the males and femaies.

\begin{tabular}{|c|c|c|c|c|c|c|c|}
\hline \multirow[b]{2}{*}{ Iocuality } & \multirow{2}{*}{\multicolumn{2}{|c|}{ Date }} & \multirow{2}{*}{$\begin{array}{c}\text { Sex } \\
\text { factor }\end{array}$} & \multicolumn{2}{|c|}{ Average number of vertebrae } & \multirow{2}{*}{$\begin{array}{c}\text { Fxcess } \\
\text { for } \\
\text { male }\end{array}$} & \multirow{2}{*}{$\begin{array}{l}\text { Signi- } \\
\text { ficance }\end{array}$} \\
\hline & & & & male & female & & \\
\hline Beppu & $\mathrm{X}$ & $28,^{\prime} 46$ & 2.25 & $45.34 \pm 0.64$ & $15.34 \pm 0.61$ & \pm 0.00 & 110 \\
\hline " & $\mathrm{XI}$ & $-25,46$ & 1.25 & $15.24 \pm 0.66$ & $45.26 \pm 0.58$ & -0.02 & no \\
\hline 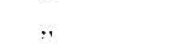 & 1 & $6,2,47$ & 1.82 & $45.02 \pm 0.61$ & $45.09 \pm 0.58$ & -0.07 & no \\
\hline Karatomati & 1 & $7, / 47$ & 1.48 & $45.13 \pm 0.55$ & $15.12 \pm 0.50$ & +0.01 & no \\
\hline Beppli & $\mathrm{I}$ & $15, "$ & 3.04 & $45.02 \pm 0.57$ & $45.08 \pm 0.62$ & $-0.06 j$ & no \\
\hline
\end{tabular}




\begin{tabular}{|c|c|c|c|c|c|c|c|}
\hline ", & II & 4,47 & 2.41 & $45.03 \pm 0.54$ & $45.06+0.50$ & -0.03 & no \\
\hline ", & & 24 , " & 1.27 & $15.10 \pm 0.57$ & $45.12 \pm 0.57$ & -0.02 & no \\
\hline ", & IIII & $3, "$ & 1.00 & $45.10 \pm 0.52$ & $45.15 \pm 0,53$ & -0.05 & no \\
\hline ", & & $17, "$ & 0.97 & $45.10 \pm 0.54$ & $45.15 \pm 0.52$ & -0.05 & no \\
\hline , & & $30, " 1$ & 0.73 & $5.15 \pm 0.58$ & $45.09 \pm 0.49$ & +0.06 & no \\
\hline Kamae & IV & 24 , " & 1.37 & $45.17 \pm 0.55$ & $45.00 \pm 0.63$ & +0.17 & yes: \\
\hline Beppu & $V$ & $24, " 1$ & 0.62 & $45.20 \pm 0.54$ & $45.18 \pm 0.66$ & +0.02 & no \\
\hline ," & VI & 19 , " & 0.69 & $45.32 \pm 0.62$ & $45.35 \pm 0.57$ & -0.03 & no \\
\hline Mean & & & 1.53 & $45.16 \pm 0.58$ & $45.15 \pm 0.66$ & +0.01 & 110 \\
\hline
\end{tabular}

There occur in the same direction the significant differences between the groups of different offsprings everywhere, but, on the contrary, there exist no significant differences between the groups of the same offspring even in different localities. Therefore, the geographical variation is unrecognizable in the number of vertebrae. However, all groups of the same offspring are not considered to belong to a unit population all around Japan, as anchovies are liable to occur densely in some different localities. The race of anchovies must be determined based upon the variation in some other morphometric characters.

The seasonal change in body length are shown graphically in Fig. 3, where the groups of winter offspring with higher vertebral number than 45.20 are indicated with black circles and those of summer offspring with lower vertebral number than 45.20 with white circles. The whitebait groups of summer offspring appear a little already in August and are dominant from September to December. Some of them attain the medium size above $50 \mathrm{~mm}$ in November, although the medium sized groups of stmmer offspring become prevalent after succeeding January till March and they attain the large size above $100 \mathrm{~mm}$ in May and June.

On the other hand, the medium sized groups of winter offspring are generally prevalent from August till December and some of them attain the large size above $100 \mathrm{~mm}$ in November. The large sized groups of winter offspring appear abundantly in the next February and March. The medium sized groups of winter offspring and the whitebait groups of summer offspring occur together from late summer to early winter on one hand and the medium sized groups of summer offspring and the large sized groups of winter offspring are present together from early winter 
till spring as was observed in Beppu Bay in 1947 (see Fig. 2). After late spring till summer, the medium sized groups of summer offspring occur together. with the whitebait groups of winter offspring. The same sized groups of different offsprings are never found together in any season and in any locality.

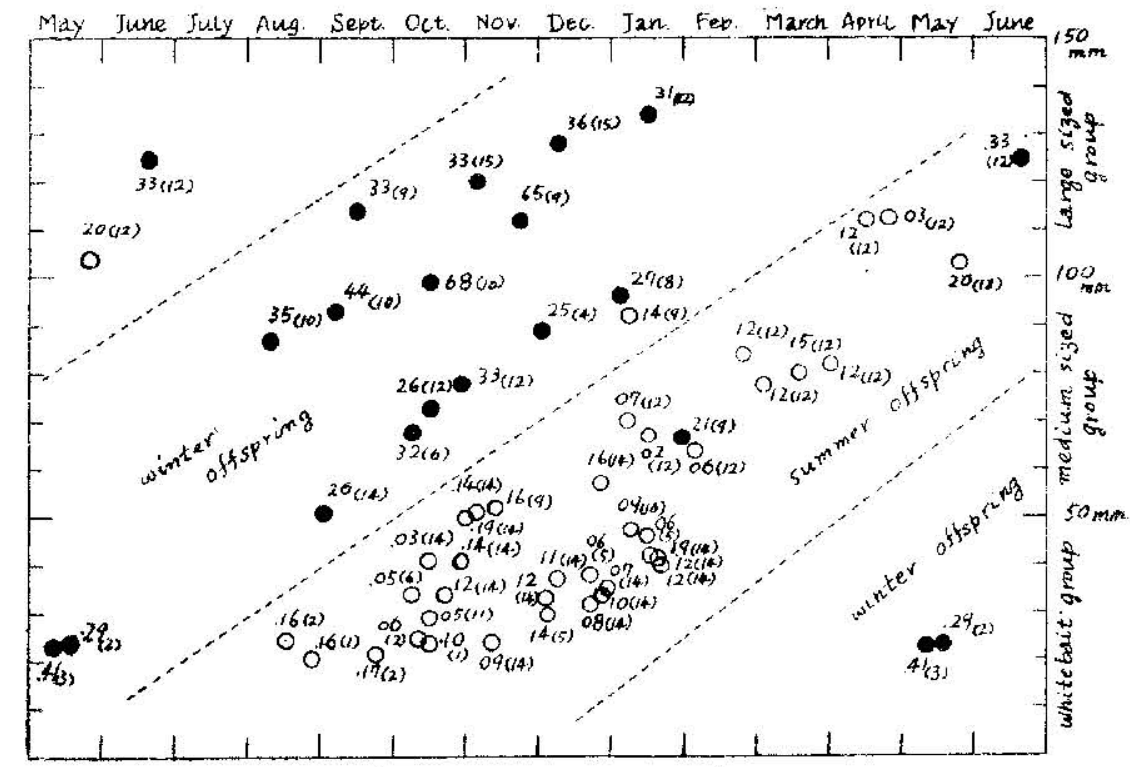

Figs. 3. Seasonal change in body length with refference to the average number of vertebrae and the locality. winter offspring, $O$ : summer offspring, number: for example. $03_{(12)}$, indicates average number of vertebrae 45.03 of the collection in St. 12 (Beppu as shown in Fig. 1).

The larvae, hatched out either in winter or in summer, are observed as whitebait group from 20 to $50 \mathrm{~mm}$ in body length luring the first six month period and as the medium sized group from 50 to 90 or $100 \mathrm{~mm}$ during the following six month period. The large sized groups above 90 or $100 \mathrm{~mm}$ in body length arc of a year old, but only a little one and a half or more years old. From scale reading for European anchovy, the body length $l_{1}$ is calculated as $80-120 \mathrm{~mm}, 1_{2}$ as $140-170 \mathrm{~mm}$, and $1_{3}$ as $160-200 \mathrm{~mm}$ respectively. Groups of one and two years old are generally dominant, but those older than two years rather scarce (Alex. 
Meek, 1916). Differing from this statement, anchovy in the Zuiderzee grows more rapidly (H. C. Redeke, 1939). Anchovy enters the Zuiderzee in April from the North Sea and spawns in June and July. In a little less than three days at a temperature varying from $14^{\circ}$ to $17^{\circ} \mathrm{C}$, the larvae hatch out and grow rapidly during summer, reaching an average length of 90 to $100 \mathrm{~mm}$ in October, then the young anchovies leave the Zuiderzee, but the greatest part, about $80 \%$, come back again next spring as nearly ripe fish and spawn, being then one year old and having grown to an average length of about $150 \mathrm{~mm}$, the remaining $20 \%$ consisted of individuals of two or exceptionally three years. During the first one year, the growth process of the anchovy of the Zuiderzec resembles much that of the Japanese anchovy. The Atlantic anchovy of :North America (E. mitchilli) is $70 \mathrm{~mm}$ in body length on an average and spawns only in summer from June to August. The northern anchovy (E. mordax mordax) of the Pacific cuast of North America is generally smaller than $150 \mathrm{~mm}$ in body length and spawns in winter off South California. American anchovies on both coast resemble the Japanese anchovy in size, but differ in the spawning habit from the latter.

The annual yield of anchovy in Japan fluctuates remarkably every year, because the young anchovies are caught as whitebait group already in two or three months after hatching out and also as medium sized group in seven or eight months. The unfavourable spawning in one season effects the catches of these small anchovits, as it cannot be easily compensated by the favourable spawning in the next season within a year. The fluctuation in catch was within the range from 1 to 4.4 off Aki in Tosa Bay (Table 11), where the anchovy fishery takes place throughout the year. Nevertheless, the range of fluctuation will be far more remarkably wide in the fishing grounds, where the rishery takes place during only a part of a year.

'lable 11. Fluctuation in catch off Aki in Tosa Bay.

\begin{tabular}{|c|c|c|c|c|c|c|c|}
\hline Year & $\begin{array}{l}\text { Catch in } \\
\text { value }\end{array}$ & Year & $\begin{array}{c}\text { Catch in } \\
\text { value }\end{array}$ & Year & $\begin{array}{l}\text { Catch in } \\
\text { value }\end{array}$ & Year & $\begin{array}{l}\text { Catch ini } \\
\text { value }\end{array}$ \\
\hline 1920 & 26124 & 1925 & $\mathrm{Y} 23023$ & 1930 & 20150 & 1935 & Ү 17596 \\
\hline $192 \mathrm{i}$ & 32579 & 1926 & 36344 & 1931 & 19800 & 1936 & 48108 \\
\hline 1922 & 34321 & 1927 & 35755 & 1932 & 20730 & 1937 & 44183 \\
\hline 1923 & 37503 & 1928 & 36238 & 1933 & 22932 & 1938 & 52208 \\
\hline 1924 & 29423 & 1929 & 37750 & 1934 & 50909 & 1934 & 7778 \\
\hline
\end{tabular}


As some of the medium sized groups of half a year old are already provided with ripe gonads, the Japanese anchovy can grow not only rapidly but also reproduce vigorously. Therefore, anchovy resource can stand against the present intense fishing and show no decreasing trend in catch anywhere, except the remarkable fluctuation.

\section{REFERENCES}

Blackburn, M. 1941, Bull. Council sci. industr. Research Commonwealth of Australia (Melbourne) no, 138; Hart, J. L. 1937, J. Biold. Bd. Canada vol. 3, no. 5; Meek, Alex. 1916, Migrations of fish. London; Nishikawa, T. 1901, J. Fish. Bur. Tokyo vol. 10, no. 1; Redeke, II. C. 1939, J. du Conseil vol. 12, no. 1 